Article

\title{
Effect of Phenological Stage and Rooting Enhancers on Physiological Parameters in Stem Cuttings in the Process of Rhizogenesis of Rosa $\times$ alba 'Maiden's Blush'
}

\author{
Marta Joanna Monder *, Maciej Niedzielski and Konrad Woliński \\ Polish Academy of Sciences Botanical Garden-Center for Biological Diversity Conservation in Powsin, \\ Prawdziwka 2, 02-973 Warsaw, Poland; m.niedzielski@obpan.pl (M.N.); k.wolinski@obpan.pl (K.W.) \\ * Correspondence: m.monder@obpan.pl; Tel.: +48-22-648-38-56
}

Received: 28 October 2020; Accepted: 20 November 2020; Published: 23 November 2020

\begin{abstract}
Once-blooming roses belong to difficult-to-root. One-bud leafy cuttings have limited storage capacity, due to the small size of the stem, and are exposed to prolonged stress conditions. The objective of this study was to examine if the treatment of the cuttings of Rosa $\times$ alba 'Maiden's Blush' with plant origin preparations as rooting enhancers may increase their rooting percentage, chlorophyll $\mathrm{a} / \mathrm{b}$, and proteins concentration in leaves. The cuttings were prepared from shoots in four phenological stages: flower buds closed, flowers open, immediately after petal shedding, and 7-14 days after petal fall. The following were used: $0.4 \%$ indole butyric acid (Ukorzeniacz $\mathrm{A}_{\text {aqua }}$ ), $0.2 \%$ naphthalene acetic acid (Ukorzeniacz $\mathrm{B}_{\text {aqua }}$ ), Bio Rhizotonic; Root Juice ${ }^{\mathrm{TM}}$, and Bio Roots. Controls included untreated cuttings. The highest rooting percentage was obtained after two treatments with $0.6 \%$ Bio Rhizotonic $(81.5 \%)$, compared to the control (55.0\%), using cuttings from shoots with flower buds closed, but the rooting enhancers did not show any unequivocal impact on rooting percentage in cuttings of all phenological stages or affected improvement this feature in cuttings harvested 7-14 after shedding petals with low root ability. However, the action of plant preparations affected positively higher soluble proteins and chlorophyll content. The plant-origin preparations can be used as alternatives to chemicals in nursery production.
\end{abstract}

Keywords: chlorophyll; carotenoids; leaf senescence; phenology; proteins; rhizogenesis; roses

\section{Introduction}

The once-blooming roses are widely considered as ornamental plants in historical and amateur gardens, parks, and urban landscape because of their tolerance to diseases and unfavorable growth conditions. Many of the Old Roses (varieties and cultivars from groups known before 1864) belong to the common winter-hardy roses [1,2]. The popularity of historical roses is significant for the overall increase of biodiversity within the currently available assortment. Rosa $\times$ alba 'Maiden's Blush' is one of the cultivars with the highest decorative value and has been cultivated since 1629 [2].

The rose cultivars can be propagated by vegetative techniques: cuttings, layers, budding, grafting, and micropropagation [1,2]. The frost-resistant shrub roses can grow from their own roots especially because of simplified cultivation $[1,3]$. One of the most economic and easy methods of propagation with cuttings is rooting of the single-node leaf cuttings from semi-wood shoots harvested during flowering time [3]. However, the flowering period of the once-blooming roses lasts only three to four weeks, during which the phenological phases transition rapidly [1,2], and research has shown the significance of that factor considering the harvest of the shoots for cuttings [3-5]. 
Propagation of cultivars originating from many rose species and Old Roses such as Rosa $\times$ alba 'Maiden's Blush' by cuttings was considered to be difficult $[1,6-9]$ and time-consuming: 10-12 weeks [1,6-8] in contrast to four to six weeks for Modern Roses [9,10].

The significant role of leaf in stem cutting of Modern Rose 'Madelon' (Hybrid Tea) propagation has been described $[9,10]$. The amount of reserves in limited storage capacity, due to the small size of shoot and leaf, is the factor regulating the survival and further growth in softwood and semi-hardwood cuttings in woody plants [11]. Photosynthesis during rhizogenesis is apparently the main regulatory factor of survival and subsequent growth (rooting, growth of the auxiliary bud into primary shoot, and dry weight accumulation) [9]. Progressive decrease of chlorophyll content and increase of carotenoids is related to leaf senescence [12,13]. Several studies [14-16] showed that seaweed extracts prevent the decrease of photosynthetic pigments, and their use is correlated with increased protein level. Their use can exhibit a positive effect on the survival of cuttings. Growth regulators (kinetin and auxins) have a significant effect on the changes in chloroplast structure and chlorophyll content of parenchymatous cells and carotenoid levels [17] and their types [18]. The use of specific growth regulators in proper concentrations inhibits chlorophyll degradation in the leaves of cut flowers, where the aging process is typically inevitable [19-21].

Biostimulants are products that reduce the requirement of fertilizers and increase plant growth; increase resistance to water and abiotic stresses; favor good performance of the plant's vital processes; enable high yields and good-quality products; and enhance nutrition efficiency and plant quality traits, regardless of its nutrient contents [22]. Research confirms the positive effect of biostimulants, including algae preparations, used in plant cultivation and propagation $[7,23,24]$. The effect of natural preparations depends on their composition, especially the content of proteins and phytohormone [14,25]. The biologically active components can stimulate various plant processes, as well as morphological and biochemical changes. They can be possibly used in nurseries to improve the efficiency of rooting $[15,16,26-28]$ and protect cuttings from diseases [16,23]. In addition, plant preparation can affect the changes in the stem anatomy of rooted cuttings [28].

To replace synthetic chemicals in plant cultivation and protection, natural preparations are used and preferred, for example, by the Official Journal of the European Union [18,19,29], National Organic Program USDA [30], and Organic Materials Review Institute [31]. An EU Council Directive [29,32] was enacted to encourage restricting the use of chemicals in overall plant production. Three commercial plant preparations recommended for rooting and replanting were used in this research: Bio Rhizotonic [33], Root Juice ${ }^{\mathrm{TM}}$ [34], and Bio Roots [35]. The previous research [5,7,28] suggested that these preparations may be successfully used in rooting of cuttings of roses.

The long duration of rhizogenesis during the vegetative propagation of one-leaf single-node stem cuttings of Rosa $\times$ alba 'Maiden's Blush' exposes the cuttings to prolonged stress and processes related to leaf senescence. The previous research showed that the contents of chlorophyll a/b, carotenoids, and soluble proteins changed in the following phenological stages of Rosa 'Maiden's Blush' shrubs [8].

Because the prolonged rhizogenesis process lasts up to 10-12 weeks, the semi-woody difficult-to-root cuttings with a limited leaf area are exposed to an extended period of stress conditions and progressive aging processes. Moreover, previous research showed that Rosa $\times$ alba 'Maiden's Blush' is especially exposed to above factors because of the early natural aging processes occurring in the growing season as described for stock plant [8]. Previous research [7] suggested that the quality and quantity of the aboveground part of cuttings, especially leaves, may correlate with the percentage of rooted cuttings in prolonged and difficult rooting of Rosa $\times$ alba 'Maiden's Blush'. The long amount of time of rhizogenesis exposes the cuttings to stress and senescence process in leaves. Additionally, a hypothesis was made that treatment of the cuttings of this rose with rooting enhancers, including, especially, plant preparations, may increase the rooting percentage and condition of leaves of cuttings [32-39]. The expected results were also increasing content of soluble proteins, chlorophyll a and $b$, and carotenoid in leaves. In the present research, the phenological stage of shoots used in propagation was also considered. It aimed to broaden the limited scientific knowledge by supporting 
the positive effects of biostimulants in the propagation of difficult-to-root plants, including roses. This research should contribute to ecofriendly propagation in nurseries.

\section{Materials and Methods}

\subsection{Plant Material and Experimental Conditions}

The plant material used was derived from the cuttings of Rosa $\times$ alba 'Maiden's Blush'. Shoots of the rose were harvested from shrubs growing in National Collection of Rose Cultivars in Polish Academy of Sciences Botanical Garden CBDC in Powsin. Single-node leafy stem cuttings were prepared from the middle part of the shoots ( $3-5$ buds, one-stock leaf area $24-27 \mathrm{~cm}^{2}$ ) in the following phenological phases (Figure 1a,b) [40]:

1. M1-flower buds closed (1 June 2012) (BBCH 54 404);

2. M2-all flowers in an inflorescence open (9 June 2012) (BBCH 69 625);

3. M3-immediately after petal shedding (17 June 2012) (BBCH 69 6N9);

4. M4-7-14 days after petal fall (28 June 2012) (BBCH 71 702).

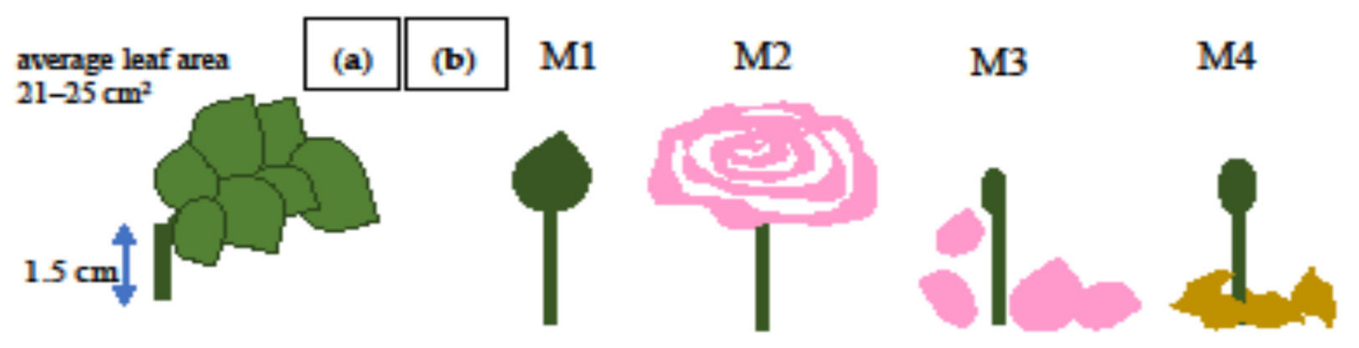

Figure 1. The single-node leaf cutting (a) and shoots of following phenological stages in terms (b) of Rosa 'Maiden's Blush' with the dates of harvesting cuttings. Phenological stages (b): M1-flower buds closed in formed inflorescence (1.06); M2-flowers in an inflorescence open (9.06); M3-immediately after petal shedding (17.06); M4-7-14 days after petal fall (28.06).

The single-node leafy stem cuttings were rooted in multipot trays $(6.6 \times 6.6 \mathrm{~cm})$, in the peat substrate ( $\mathrm{pH}$ 6-6.5). The control cuttings were watered with $10 \mathrm{~mL}$ water per pot, while the other cuttings were prepared with biostimulants of standard rooting preparations. Suitable combinations of the intended cuttings were treated with standard commercial rooting preparations that can support rhizogenesis-Ukorzeniacz $\mathrm{A}_{\text {aqua }}\left(0.4 \%\right.$ IBA) and Ukorzeniacz $\mathrm{B}_{\text {aqua }}(0.2 \%$ NAA) (Himal, Poland)—by dipping the $1 \mathrm{~cm}$ basal part of the cutting in either preparation for $1 \mathrm{~s}$. Then, the cuttings were inserted into the peat substrate and watered with $10 \mathrm{~mL}$ water per pot, using an automatic laboratory pipette dispenser. The other part of the intended cuttings was watered with solutions of the following plant preparations: Bio Rhizotonic (Canna Continental, LA, USA), Root Juice ${ }^{\mathrm{TM}}$ (BioBizz Worldwide B.V., Groningen, The Netherlands), and Bio Roots (General Hydroponics Europe, Fleurance, France) (Table 1).

The cuttings rooted in standard conditions in a foil tunnel with the electronically controlled misting system maintained the appropriate climatic conditions (air temperature of $23-25^{\circ} \mathrm{C}$, ambient relative humidity of $80-90 \%)$ in the commercial nursery of M. M. Kryt in Wola Prażmowska $\left(51.56^{\circ} \mathrm{N}\right.$, $20.28^{\circ} \mathrm{E}$ ). The shading material reduced the photosynthetic photon flux density to $130 \mu \mathrm{moL} \cdot \mathrm{m}^{-2} \cdot \mathrm{s}^{-1}$. The cuttings were protected from fungal diseases by applying fungicides once on the day of planting and after 7-9 days regularly. 
Table 1. Plant origin preparations used to root Rosa $\times$ alba 'Maiden's Blush' in the experiment.

\begin{tabular}{|c|c|c|}
\hline Preparation & Characteristic & Certificate \\
\hline $\begin{array}{c}\text { Bio Rhizotonic } \\
\text { (Canna Continental, } \\
\text { 2017) }\end{array}$ & $\begin{array}{l}\text { seaweed-based, } 100 \% \text { organic and contains } \\
\text { N-P-K } 0.6-0.2-0.6 \text {, vitamins such as B1 and } \\
\text { B2, and other biologically active substances }\end{array}$ & $\begin{array}{l}\text { Organic Materials Review Institute } \\
\text { (OMRI) }\end{array}$ \\
\hline $\begin{array}{l}\text { Root Juice }^{\mathrm{TM}} \\
\text { (BioBizz Worldwide B.V. } \\
\text { 2017) }\end{array}$ & $\begin{array}{l}\text { combination of humic acid and seaweed } \\
\text { extracts, containing N-P-K 2-6-6 }\end{array}$ & $\begin{array}{l}\text { National Organic Program (NOP); } \\
\text { Control Union Certified EU; Good } \\
\text { Soil Quality Mark; Point Vert; } \\
\text { Organic Materials Review Institute } \\
\text { (OMRI), Clean Green Certified }\end{array}$ \\
\hline $\begin{array}{l}\text { Bio Roots } \\
(\mathrm{GHE}, 2017)\end{array}$ & $\begin{array}{c}\text { amino acids and oligosaccharins, fruit oil up } \\
\text { to } 1 \% \text {; humic acids } 1 \% \text {; pectinate } 1 \% \text {; } \\
\text { sodium alginate } 3 \% \text {; seaweed species } 10 \% \text {, } \\
\text { organic matter } 84 \%\end{array}$ & $\begin{array}{l}\text { European regulation EC No } \\
\text { 834/2007 on organic agriculture } \\
\text { (Certificaat Bio Roots 2014). }\end{array}$ \\
\hline
\end{tabular}

During the next irrigation term, the cuttings were watered with $10 \mathrm{~mL}$ water per pot or the appropriate concentration of Bio Rhizotonic. The treatments were conducted according to the producer's instructions. The treatment with the watering process is described in detail in Table 2 and presented in Figure 2.

Table 2. The auxin and plant origin preparation treatments of cuttings of Rosa 'Maiden's Blush' at each phenology stage in the research.

\begin{tabular}{ccc}
\hline No. of Treatment & Treatment of Cuttings \\
\hline 1 & & Control \\
2 & & Ukorzeniacz A Aqua $0.4 \%$ IBA \\
3 & Ukorzeniacz Baqua $0.2 \%$ NAA \\
4 & $0.4 \%$ Bio Rhizotonic & watering $(10 \mathrm{~mL})$ after cutting \\
5 & $0.6 \%$ Bio Rhizotonic & \\
6 & $0.4 \%$ Bio Rhizotonic & watering $(10 \mathrm{~mL})$ after cutting and 10 days later \\
7 & $0.6 \%$ Bio Rhizotonic & \\
8 & $0.4 \%$ Bio Rhizotonic & watering $(10 \mathrm{~mL})$ after cuttings, 10 and 20 days later \\
9 & $0.6 \%$ Bio Rhizotonic & \\
10 & $0.1 \%$ RootJuice & \\
11 & $0.2 \%$ RootJuice & \\
12 & $0.4 \%$ RootJuice & \\
13 & $0.012 \%$ Bio Roots & \\
14 & $0.02 \%$ Bio Roots & \\
\hline
\end{tabular}

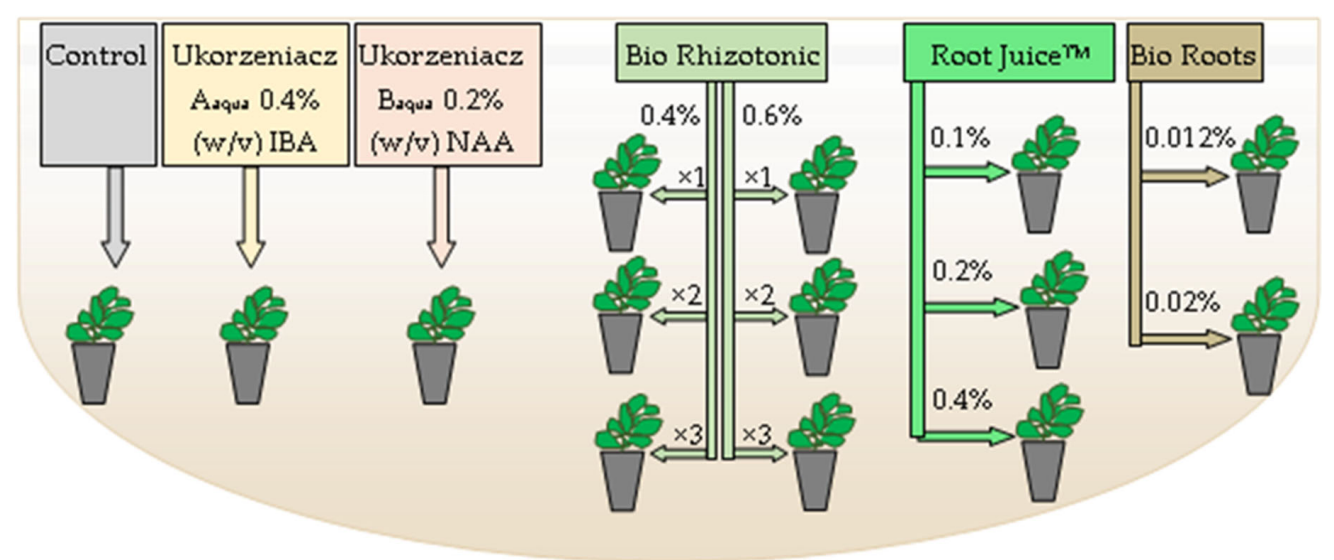

Figure 2. The scheme of the experiment treatments of rose cuttings with rooting stimulants in each of four shoot phenological stages. 


\subsection{Evaluation of Rooted Cuttings}

The cuttings were dug out after 12 weeks. The rooted cuttings (with visible roots on the node or basal part of stem) were separated for further evaluation. The rooted cuttings with retained stock plant leaf and separately with the new shoot were calculated.

The rooting percentage (\%) were recorded according to the number of planted cuttings (a), while the percentage of cuttings with retained stock plant leaf $(\mathbf{b})$ and the cuttings that formed a new shoot were recorded according to the number of rooted cuttings (c):

$$
x=\frac{[(\mathrm{a} \cdot 100 \%): 20]+[(\mathrm{b} \cdot 100 \%): 20]+[(\mathrm{c} \cdot 100 \%): 20]+[(\mathrm{d} \cdot 100 \%): 20]}{4}
$$

where $x$-rooting percentage of treatment; $\mathrm{a}$-number of rooted cuttings in first repetition; $\mathrm{b}-$ number of rooted cuttings in second repetition; $c$-number of rooted cuttings in third repetition; and $d$-number of rooted cuttings in fourth repetition.

$$
y=\frac{[(\mathrm{e} \cdot 100 \%): \mathrm{i}]+[(\mathrm{f} \cdot 100 \%): \mathrm{j}]+[(\mathrm{g} \cdot 100 \%): \mathrm{k}]+[(\mathrm{h} \cdot 100 \%): \mathrm{l}]}{4}
$$

where $y$-percentage of cuttings with retained stock plant leaf; $\mathrm{e}, \mathrm{f}, \mathrm{g}$, and $\mathrm{h}$-numbers of cuttings with retained stock plant leaf in following repetition; $\mathrm{i}, \mathrm{j}, \mathrm{k}$, and $\mathrm{l}$-numbers of rooted cuttings, respectively, in the following repetition.

$$
z=\frac{[(\mathrm{m} \cdot 100 \%): \mathrm{r}]+[(\mathrm{n} \cdot 100 \%): \mathrm{s}]+[(\mathrm{o} \cdot 100 \%): \mathrm{t}]+[(\mathrm{p} \cdot 100 \%): \mathrm{t}]}{4}
$$

where $z$-percentage of cuttings formed a new shoot of treatment; $m, n, o$, and $p$-numbers of cuttings that formed a new shoot in following repetition; r, s, t, and u-numbers of rooted cuttings, respectively, in the following repetition.

The cuttings were evaluated to measure the length of the new shoot from its base to the apical meristem of this shoot. The total leaf area $\left(\mathrm{cm}^{2}\right.$, original leaf with all leaves on the new shoot) were scanned with a leaf area meter (AM 300, ADC BioScientific Ltd., Hoddesdon, UK).

For biochemical analyses of the soluble protein fraction, as well as the measurement of the amount of chlorophyll $\mathrm{a} / \mathrm{b}$ and carotenoids, the leaves were sampled after 12 weeks of rooting period (from rooted segments of shoots-the leaf derived from stock plant only).

The samples for biochemical analyses were frozen and maintained at a temperature of $-18^{\circ} \mathrm{C}$. Research was conducted in the laboratories of PAS Botanical Garden CBDC in Powsin.

\subsection{Protein Extraction and Analyse}

The protein extract was used for evaluating the content of soluble proteins [41]. The frozen leaf sample of around $100 \mathrm{mg}$ was extracted three times (30 min each) with $1 \mathrm{~mL}$ of extraction buffer ( $0.063 \mathrm{M}$ Tris, $2 \%$ SDS, 5\% $\beta$-mercaptoethanol, 10\% glycerol). Each sample was denatured for $5 \mathrm{~min}$, in a water bath, at $98{ }^{\circ} \mathrm{C}$, and subsequently centrifuged at room temperature, for $20 \mathrm{~min}$, at $10,000 \times g$. Protein concentration was assessed according to the modified method of [42]. Soluble protein content was measured with $10 \mu \mathrm{L}$ portions of the supernatant. The samples were marked on squares of Whatman $3 \mathrm{MM}$ blotting paper placed in cells of cultivation plates. After drying at $35{ }^{\circ} \mathrm{C}$ for discoloration, $15 \mu \mathrm{L}$ of CBB R-250 (0.2\%) solution in ( $40 \%)$ methanol and (10\%) acetic acid was sprinkled on the blotting paper for $20 \mathrm{~min}$. Then, the excess colors were eluted with methanol and acetic acid and dried. The samples were moved to test tubes, and the protein-pigment complex was eluted with $1 \%$ SDS in an ultrasonic washer for $1 \mathrm{~h}$. Absorption of the eluate was assessed at a wavelength of $590 \mathrm{~nm}$ (spectrophotometer Gene Quant 1300, GE). The soluble protein content was calculated by using the standard curve for the BSA solutions. 


\subsection{Chlorophyll and Carotenoid Analyses}

Leaf tissue sample of $0.1 \mathrm{~g}$ was ground to a powder in liquid nitrogen, using a mortar and pestle, followed by extraction with $5 \mathrm{~mL}$ of $99.5 \%$ acetone by adding a pinch of calcium carbonate to neutralize the organic acids. The extracts were made up to a total volume of $25 \mathrm{~mL}$ with acetone and filtered through a soft blotting paper, and the content of the pigments was assessed spectrophotometrically, by measuring the absorbance at wavelengths of 750, 662, 645, and $470 \mathrm{~nm}$ (GeneQuant 1300, GE). The content of chlorophyll $\mathrm{a} / \mathrm{b}$ and carotenoids was calculated according to the following formulas [43]:

$$
\begin{gathered}
\text { Chlorophyll a }=\left(12.7 \times \mathrm{A}_{663}-2.7 \times \mathrm{A}_{645}\right) \times \mathrm{V} \times(1000 \mathrm{~W})^{-1} \\
\text { Chlorophyll } \mathrm{b}=\left(22.9 \times \mathrm{A}_{645}-4.7 \times \mathrm{A}_{663}\right) \times \mathrm{V} \times(1000 \mathrm{~W})^{-1} \\
\text { Carotenoids }=\left(1000 \times \mathrm{M}_{470}-1.9 \times \text { chlorophyll a }-63.14 \times \text { chlorophyll } \mathrm{b}\right) \times 214^{-1}
\end{gathered}
$$

where $\mathrm{A}$-absorbance at a given wavelength, $\mathrm{V}$-total volume of the extract $\left(\mathrm{cm}^{3}\right)$, and $\mathrm{W}$ - sample weight $(\mathrm{g})$. The content of the chlorophyll $\mathrm{a} / \mathrm{b}$ was measured in $\mathrm{mg} \mathrm{g}^{-1}$ of fresh weight, and that of the carotenoids in $\mathrm{mg} \cdot \mathrm{g}^{-1}$ of fresh weight.

\subsection{Statistical Analysis}

A randomized complete block design for experiments was constructed. In each studied treatment in phenological phase (Table 2), 20 cuttings were planted in four replicas (14 statistical combinations; 4480 cuttings together in experiment). The content of proteins and pigments in leaves was determined for six repeats in each combination. To compare the means, the values in percentage were transformed by using the function $\operatorname{ARCSIN}(x)^{1 / 2}$ according to Bliss or $y=x^{2}+\left(x^{2}+1\right)^{2}$ [44]. The contents of proteins and pigments in leaves were determined for six repeats.

The results were analyzed by using one- or two-factorial analysis of variance (ANOVA), and Duncan's Honest Significant Difference test was used to determine the significance of differences between the means $(p \leq 0.05)$. The correlation analyses between rooting percentage and the percentage of cuttings with retained stock plant leaf, the cuttings that formed a new shoot, total leaf area, and concentrations of biologically active components after rooting in relation to phenological stage of the stock plants were performed [44]. STATISTICA 10 software package (Statsoft Polska, Kraków, Poland) was used for statistical analysis.

\section{Results}

\subsection{The Rooting Enhancers Affect Variously the Changes in Leaf Tissues and the Quality and Quantity of Rooted Cuttings Harvested in Four Phenology Stages}

The cuttings harvested from shoots with flower buds closed (M1).

The highest rooting percentage of the stem cuttings of Rosa 'Maiden's Blush' harvested from shoots with flower buds closed (M1) was obtained after twice treatment with $0.6 \%$ Bio Rhizotonic $(81.3 \%)$, compared to the control (55.0\%) (Figure 3). None of the preparations improved the percentage of cuttings with retained stock plant leaf (Figure 4), percentage of cuttings with young shoots (Figure 5), or total leaf area (Figure 6). The only advantage of the use of $0.2 \%$ Root Juice $^{\mathrm{TM}}$ is that it has a positive effect on the length of young shoots (Figure 7). The use of NAA and one-time watering with $0.6 \%$ Bio Rhizotonic, and two-time watering with $0.4 \%$ Bio Rhizotonic, $0.2 \%$ Root Juice ${ }^{\mathrm{TM}}$, and $0.12 \%$ Bio Roots preparations increased the content of chlorophyll a/b in leaves, while single treatment with $0.6 \%$ Bio Rhizotonic, $0.2 \%$ Root Juice ${ }^{\mathrm{TM}}$, and $0.12 \%$ Bio Roots increased the content of carotenoids compared to control ( Figures 8-10). None of the preparations improved the value of soluble protein content in the leaves of stem cuttings of 'Maiden's Blush' cut from shoots with all the buds closed (Figure 11). 


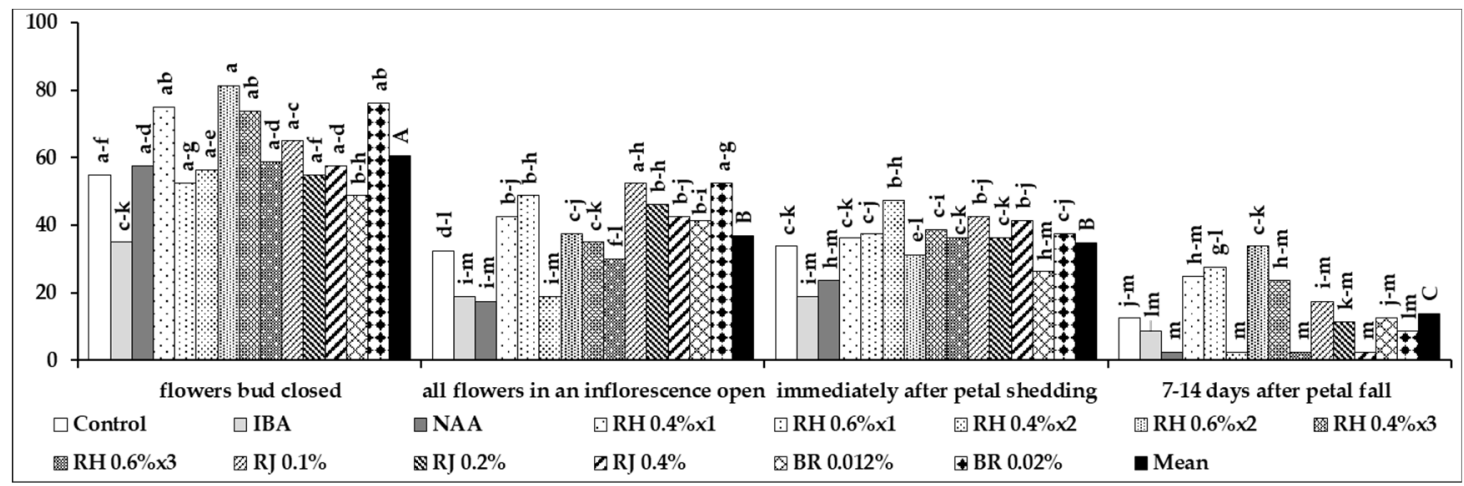

Figure 3. The influence of rooting enhancers on rooting percentage (\%) of cuttings of Rosa 'Maiden's Blush' harvested in four phenological stages of shoot. Control一the control cuttings; IBA $0.4 \%$-Ukorzeniacz A aqua (0.4\% IBA); NAA 0.2\%-Ukorzeniacz Baqua ( $0.2 \%$ NAA); RH $0.4 \% \times 1$, RH $0.6 \% \times 1$-watering with $0.4 \%$ or $0.6 \%$ Bio Rhizotonic $(10 \mathrm{~mL})$ after planting; $\mathrm{RH} 0.4 \% \times 2$, RH $0.6 \% \times 2$-watering with $0.4 \%$ or $0.6 \%$ Bio Rhizotonic $(10 \mathrm{~mL})$ after planting and 10 days later; RH $0.4 \% \times 3$, RH $0.6 \% \times 3$-watering with $0.6 \%$ Bio Rhizotonic $(10 \mathrm{~mL})$ after planting, 10 and 20 days later; RJ $0.1 \%$, RJ $0.2 \%$, RJ $0.4 \%$-watering with $0.1 \%, 0.2 \%$ or $0.4 \%$ Root Juice ${ }^{\mathrm{TM}}(10 \mathrm{~mL})$ after planting; BR $0.012 \%$, BR $0.02 \%$-watering with $0.012 \%$ or $0.02 \%$ Bio Roots $(10 \mathrm{~mL})$ after planting. Different small letters indicate significant interactions between phenological stage and treatment (two-way ANOVA). Different capital letters indicate significant differences between phenological stages. The Duncan's test $(\alpha=0.05)$ was used.

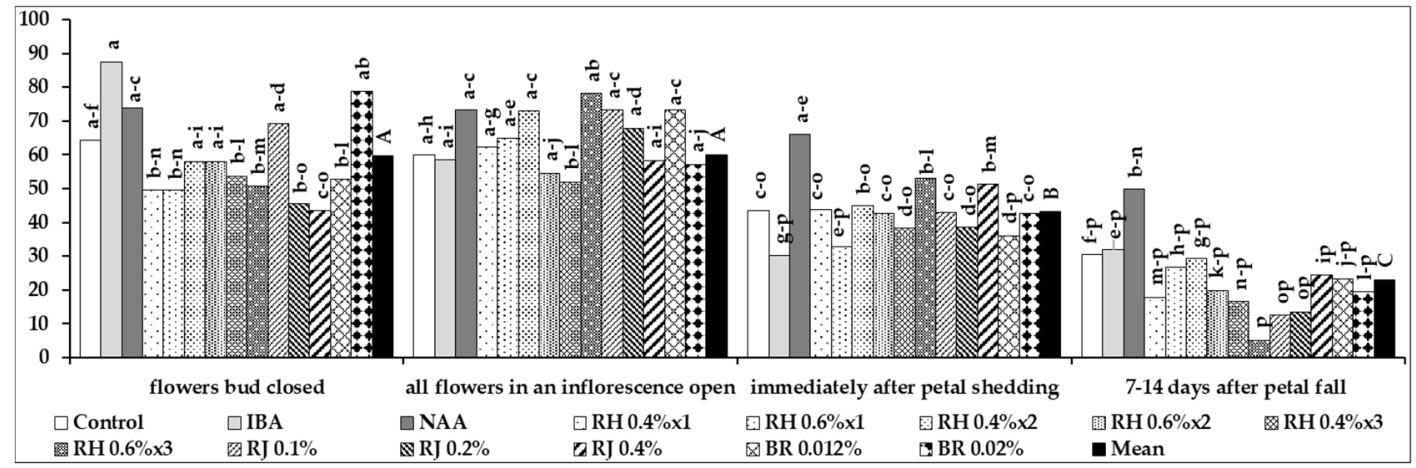

Figure 4. The influence of rooting enhancers on percentage of rooted cuttings with retained stock plant leaf (\%) of Rosa 'Maiden's Blush' harvested in four phenological stages of shoot. Control—the control cuttings; IBA $0.4 \%$-Ukorzeniacz A aqua $(0.4 \%$ IBA); NAA $0.2 \%$-Ukorzeniacz Baqua $(0.2 \%$ NAA); RH $0.4 \% \times 1$, RH $0.6 \% \times 1$-watering with $0.4 \%$ or $0.6 \%$ Bio Rhizotonic $(10 \mathrm{~mL})$ after planting; $\mathrm{RH} 0.4 \% \times 2$, RH $0.6 \% \times 2$-watering with $0.4 \%$ or $0.6 \%$ Bio Rhizotonic $(10 \mathrm{~mL})$ after planting and 10 days later; RH $0.4 \% \times 3$, RH $0.6 \% \times 3$-watering with $0.6 \%$ Bio Rhizotonic $(10 \mathrm{~mL})$ after planting, 10 and 20 days later; RJ $0.1 \%$, RJ $0.2 \%$, RJ $0.4 \%$-watering with $0.1 \%, 0.2 \%$ or $0.4 \%$ Root Juice ${ }^{\mathrm{TM}}(10 \mathrm{~mL})$ after planting; BR $0.012 \%$, BR $0.02 \%$-watering with $0.012 \%$ or $0.02 \%$ Bio Roots $(10 \mathrm{~mL})$ after planting. Different small letters indicate significant interactions between phenological stage and treatment (two-way ANOVA). Different capital letters indicate significant differences between phenological stages. The Duncan's test $(\alpha=0.05)$ was used.

The cuttings harvested from shoots with all flowers in an inflorescence open (M2).

In the case of 'Maiden's Blush' cut from the shoots with all flowers opened, none of the preparations improved the rooting percentage (Figure 3), percentage of cuttings with retained stock plant leaf (Figure 4), percentage of cuttings with young shoots (Figure 5), or total leaf area (Figure 6). The single use of $0.4 \%$ Bio Rhizotonic increased the length of young shoots (Figure 7 ). The increase in the chlorophyll a and b concentration was caused by using NAA commercial preparation (Figures 8 and 9), in addition to the increase in the carotenoids by single watering with 0.6\% Bio Rhizotonic (Figure 10). 
The soluble protein content increased in the leaves after the use of all concentrations of Bio Rhizotonic, $0.1 \%$ and $0.4 \%$ Root Juice ${ }^{\mathrm{TM}}$, and $0.012 \%$ Bio Roots (Figure 11 ).

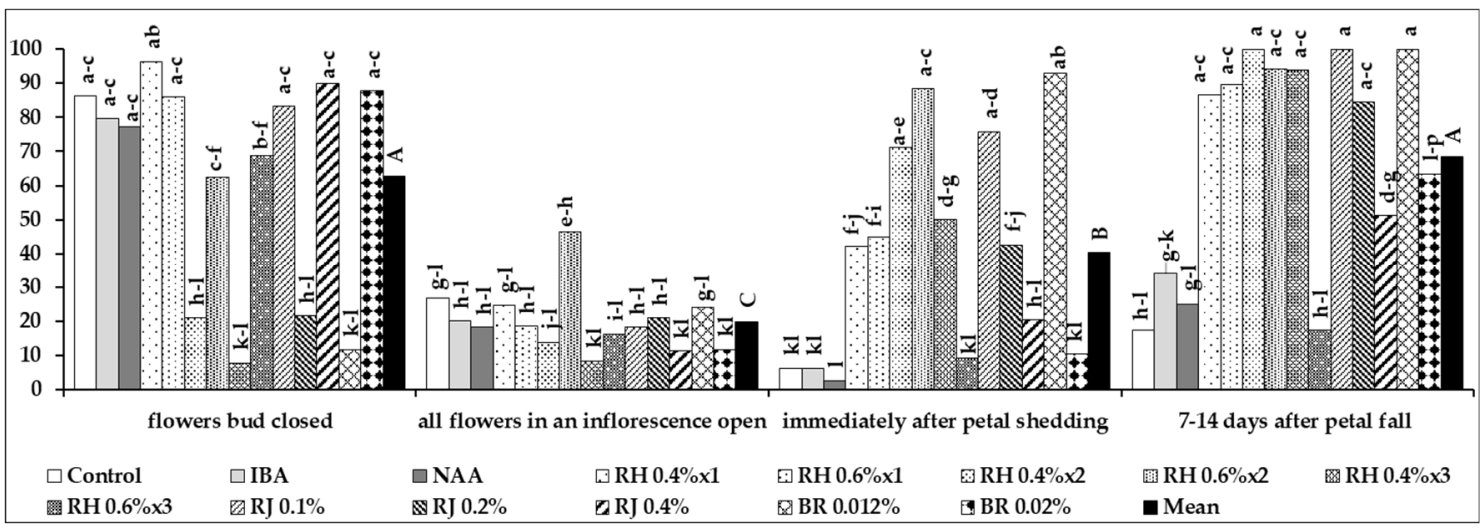

Figure 5. The influence of rooting enhancers on percentage of rooted cuttings created new shoot (\%) in Rosa 'Maiden's Blush' harvested in four phenological stages of shoot. Control-the control cuttings; IBA $0.4 \%$-Ukorzeniacz A $\mathrm{A}_{\text {aqua }}\left(0.4 \%\right.$ IBA); NAA $0.2 \%$-Ukorzeniacz $\mathrm{B}_{\text {aqua }}(0.2 \%$ NAA); RH $0.4 \% \times 1$, RH $0.6 \% \times 1$-watering with $0.4 \%$ or $0.6 \%$ Bio Rhizotonic $(10 \mathrm{~mL})$ after planting; $\mathrm{RH} 0.4 \% \times 2$, RH $0.6 \% \times 2$-watering with $0.4 \%$ or $0.6 \%$ Bio Rhizotonic $(10 \mathrm{~mL})$ after planting and 10 days later; RH $0.4 \% \times 3$, RH $0.6 \% \times 3$-watering with $0.6 \%$ Bio Rhizotonic $(10 \mathrm{~mL})$ after planting, 10 and 20 days later; RJ $0.1 \%$, RJ $0.2 \%$, RJ $0.4 \%$-watering with $0.1 \%, 0.2 \%$, or $0.4 \%$ Root Juice ${ }^{\mathrm{TM}}(10 \mathrm{~mL})$ after planting; BR $0.012 \%$, BR $0.02 \%$-watering with $0.012 \%$ or $0.02 \%$ Bio Roots $(10 \mathrm{~mL})$ after planting. Different small letters indicate significant interactions between phenological stage and treatment (two-way ANOVA). Different capital letters indicate significant differences between phenological stages. The Duncan's test $(\alpha=0.05)$ was used.

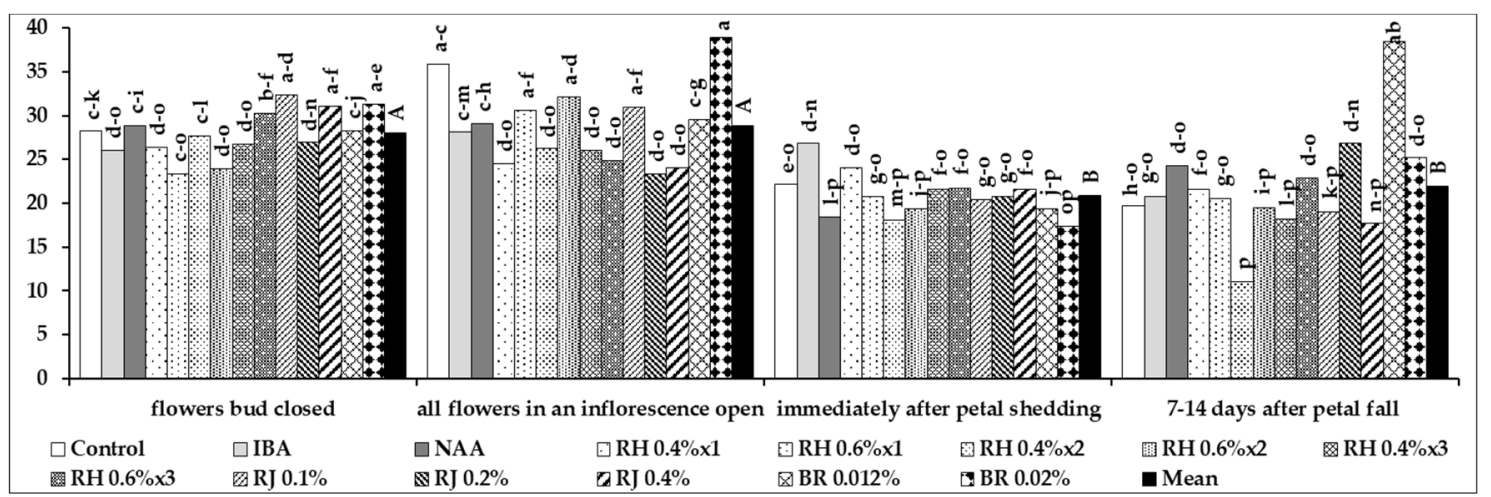

Figure 6. The influence of rooting enhancers on total leaf area $\left(\mathrm{cm}^{2}\right)$ in Rosa 'Maiden's Blush' cuttings harvested in four phenological stages of shoot. Control—the control cuttings; IBA $0.4 \%$-Ukorzeniacz $\mathrm{A}_{\text {aqua }}(0.4 \%$ IBA); NAA $0.2 \%$-Ukorzeniacz Baqua $(0.2 \%$ NAA); RH $0.4 \% \times 1$, RH $0.6 \% \times 1$-watering with $0.4 \%$ or $0.6 \%$ Bio Rhizotonic $(10 \mathrm{~mL})$ after planting; $\mathrm{RH} 0.4 \% \times 2$, $\mathrm{RH} 0.6 \% \times 2$-watering with $0.4 \%$ or $0.6 \%$ Bio Rhizotonic $(10 \mathrm{~mL})$ after planting and 10 days later; $\mathrm{RH} 0.4 \% \times 3, \mathrm{RH} 0.6 \% \times 3$-watering with $0.6 \%$ Bio Rhizotonic (10 mL) after planting, 10 and 20 days later; RJ $0.1 \%$, RJ $0.2 \%$, RJ $0.4 \%$-watering with $0.1 \%, 0.2 \%$, or $0.4 \%$ Root Juice ${ }^{\mathrm{TM}}(10 \mathrm{~mL})$ after planting; BR $0.012 \%$, BR $0.02 \%$-watering with $0.012 \%$ or $0.02 \%$ Bio Roots $(10 \mathrm{~mL})$ after planting. Different small letters indicate significant interactions between phenological stage and treatment (two-way ANOVA). Different capital letters indicate significant differences between phenological stages. The Duncan's test $(\alpha=0.05)$ was used. 


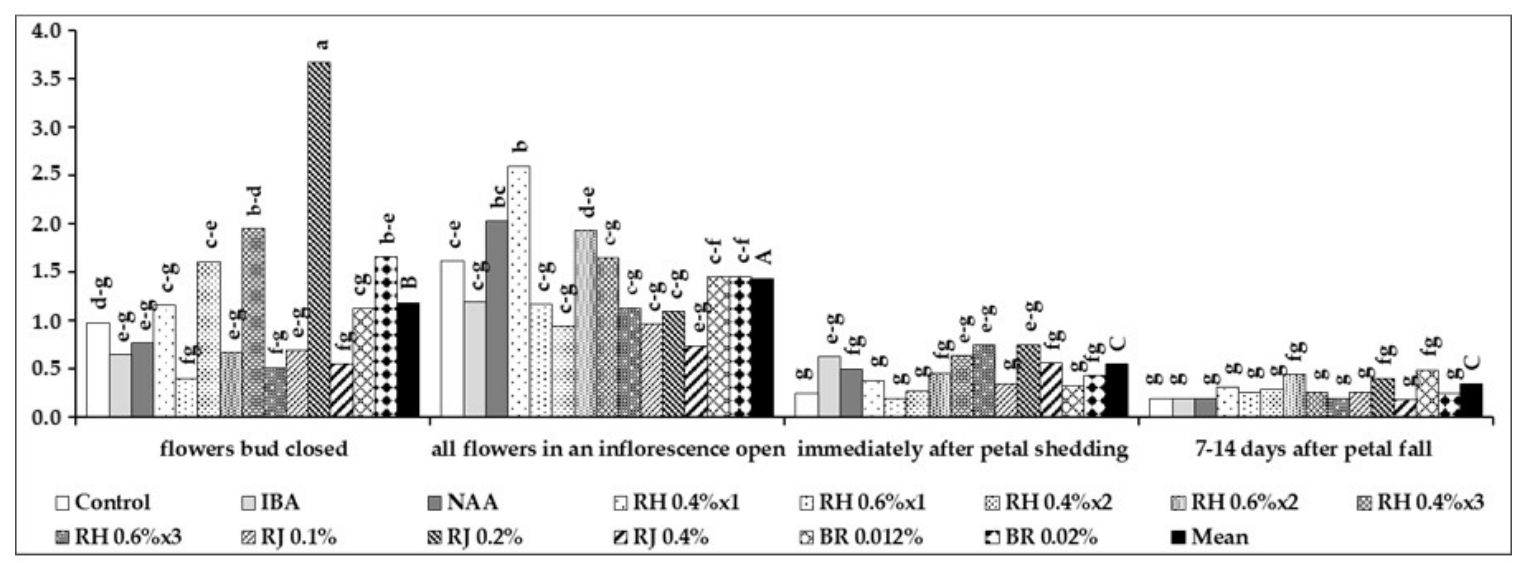

Figure 7. The influence of rooting enhancers on length $(\mathrm{cm})$ of shoot in Rosa 'Maiden's Blush' cuttings harvested in four phenological stages of shoot. Control一the control cuttings; IBA $0.4 \%$-Ukorzeniacz $\mathrm{A}_{\text {aqua }}(0.4 \%$ IBA); NAA $0.2 \%$-Ukorzeniacz Baqua $(0.2 \%$ NAA); RH $0.4 \% \times 1$, RH $0.6 \% \times 1$-watering with $0.4 \%$ or $0.6 \%$ Bio Rhizotonic $(10 \mathrm{~mL})$ after planting; $\mathrm{RH} 0.4 \% \times 2$, RH $0.6 \% \times 2$-watering with $0.4 \%$ or $0.6 \%$ Bio Rhizotonic $(10 \mathrm{~mL})$ after planting and 10 days later; $\mathrm{RH} 0.4 \% \times 3, \mathrm{RH} 0.6 \% \times 3$-watering with $0.6 \%$ Bio Rhizotonic (10 mL) after planting, 10 and 20 days later; RJ $0.1 \%$, RJ $0.2 \%$, RJ $0.4 \%$-watering with $0.1 \%, 0.2 \%$, or $0.4 \%$ Root Juice ${ }^{\mathrm{TM}}(10 \mathrm{~mL})$ after planting; BR $0.012 \%$, BR $0.02 \%$-watering with $0.012 \%$ or $0.02 \%$ Bio Roots $(10 \mathrm{~mL})$ after planting. Different small letters indicate significant interactions between phenological stage and treatment (two-way ANOVA). Different capital letters indicate significant differences between phenological stages. The Duncan's test $(\alpha=0.05)$ was used.

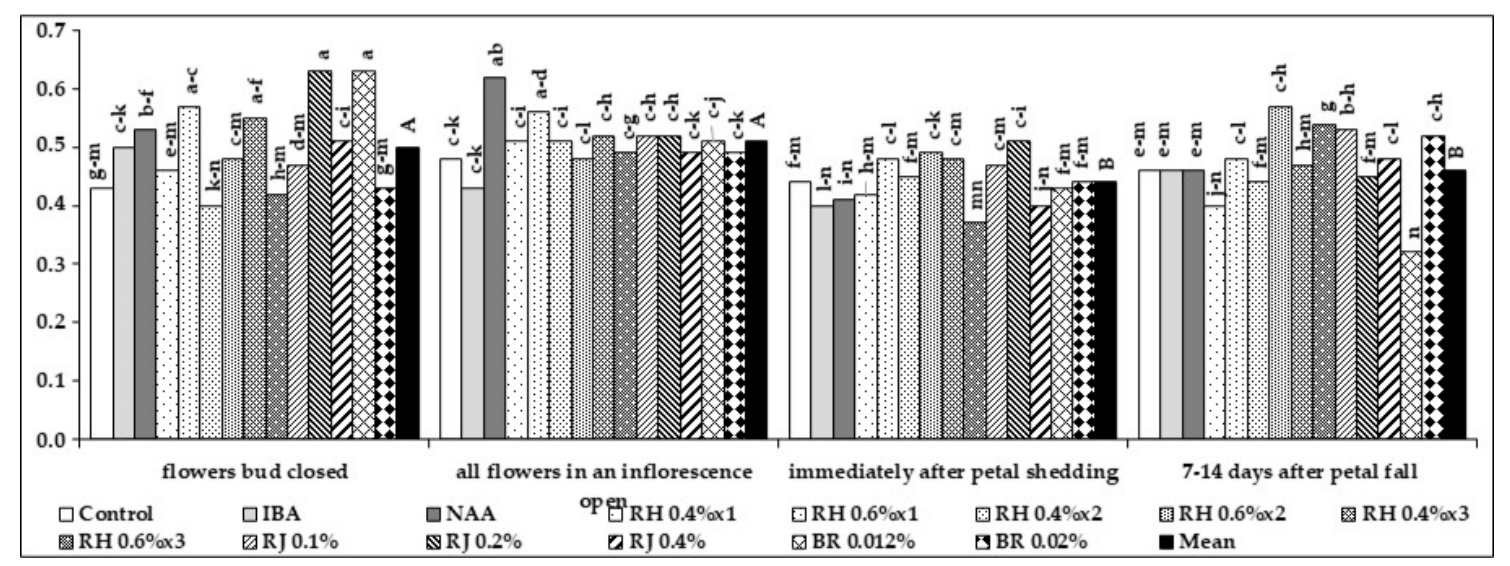

Figure 8. The influence of rooting enhancers on chlorophyll a content ( $\left.\mathrm{mg} \mathrm{g}^{-1} \mathrm{FW}\right)$ in leaves of Rosa 'Maiden's Blush' cuttings harvested from shoots in four phenological stages of shoots. Control-the control cuttings; IBA $0.4 \%$-Ukorzeniacz A aqua $\left(0.4 \%\right.$ IBA); NAA $0.2 \%$-Ukorzeniacz B $\mathrm{B}_{\text {aqua }}(0.2 \%$ NAA); RH $0.4 \% \times 1$, RH $0.6 \% \times 1$-watering with $0.4 \%$ or $0.6 \%$ Bio Rhizotonic $(10 \mathrm{~mL})$ after planting; $\mathrm{RH} 0.4 \% \times 2$, RH $0.6 \% \times 2$-watering with $0.4 \%$ or $0.6 \%$ Bio Rhizotonic $(10 \mathrm{~mL})$ after planting and 10 days later; RH $0.4 \times 3$, RH $0.6 \% \times 3$-watering with $0.6 \%$ Bio Rhizotonic $(10 \mathrm{~mL})$ after planting, 10 and 20 days later; RJ $0.1 \%$, RJ $0.2 \%$, RJ $0.4 \%$-watering with $0.1 \%, 0.2 \%$, or $0.4 \%$ Root Juice ${ }^{\mathrm{TM}}(10 \mathrm{~mL})$ after planting; BR $0.012 \%$, BR $0.02 \%$-watering with $0.012 \%$ or $0.02 \%$ Bio Roots $(10 \mathrm{~mL})$ after planting. Different small letters indicate significant interactions between phenological stage and treatment (two-way ANOVA). Different capital letters indicate significant differences between phenological stages. The Duncan's test $(\alpha=0.05)$ was used.

The cuttings harvested from shoots immediately after petal shedding (M3).

None of the preparations improved the values of rooting percentage (Figure 3), percentage of cuttings with retained stock plant leaf (Figure 4), total leaf area (Figure 6), or content of chlorophyll a/b and carotenoids (Figures 8-10), in the cuttings of 'Maiden's Blush' derived from shoots immediately 
after shedding petals. However, the beneficial effects of watering, triple treatment with $0.4 \%$ Bio Rhizotonic, two-time watering with $0.6 \%$ Bio Rhizotonic, $0.1 \%$ and $0.2 \%$ Root Juice ${ }^{\mathrm{TM}}$, and $0.012 \%$ Bio Roots on the percentage of the cuttings that formed a new shoot were recorded (Figure 5). The $0.2 \%$ NAA had a positive effect on increasing the length of new shoots (Figure 7). The concentration of soluble proteins in leaves increased after the use of $0.012 \%$ Bio Roots (Figure 11) and twice watering with $0.06 \%$ Bio Rhizotonic. Moreover, the contents of chlorophyll $\mathrm{a} / \mathrm{b}$ and carotenoids decreased after triple treatment with $0.6 \%$ Bio Rhizotonic (Figures 8-10), while $0.2 \%$ NAA preparation (Figure 11) decreased the soluble protein content.

The cuttings harvested from shoots 7-14 days after petal fall (M4).

The rooting percentage (Figure 3), percentage of cuttings with retained stock plant leaf (Figure 4), total leaf area (Figure 6), length of the shoots (Figure 7), and content of proteins, chlorophyll a/b, and carotenoids (Figures 8-10) did not increase after using the rooting enhancers in the cuttings of 'Maiden's Blush' derived from shoots 7-14 days after shedding petals. The percentage of cuttings that formed a new shoot increased after watering them with Root Juice ${ }^{\mathrm{TM}}$ and Bio Roots, triple treatment with $0.4 \%$ Bio Rhizotonic, and twice treatment with $0.6 \%$ Bio Rhizotonic (Figure 5). The content of chlorophyll $\mathrm{a} / \mathrm{b}$ and carotenoids in leaves decreased after the use of $0.012 \%$ Bio Roots (Figures $8-10$ ), and soluble protein content decreased after one-time watering with $0.4 \%$ Bio Rhizotonic (Figure 11).

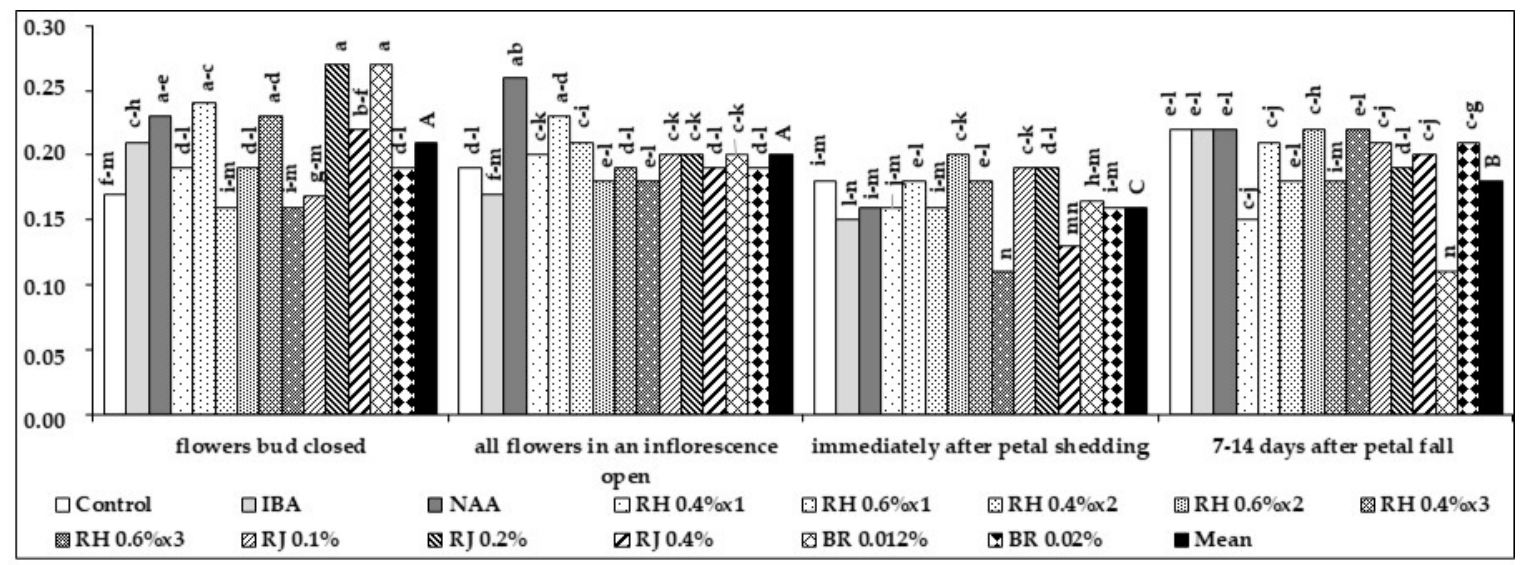

Figure 9. The influence of rooting enhancers on chlorophyll b content $\left(\mathrm{mg} \mathrm{g}^{-1} \mathrm{FW}\right)$ in leaves of Rosa 'Maiden's Blush' cuttings harvested from shoots in four phenological stages of shoots. Control—the control cuttings; IBA $0.4 \%$-Ukorzeniacz A Aqua $(0.4 \%$ IBA); NAA $0.2 \%$-Ukorzeniacz Baqua $(0.2 \%$ NAA); RH $0.4 \% \times 1$, RH $0.6 \% \times 1$-watering with $0.4 \%$ or $0.6 \%$ Bio Rhizotonic $(10 \mathrm{~mL})$ after planting; $\mathrm{RH} 0.4 \% \times 2$, $\mathrm{RH} 0.6 \% \times 2$-watering with $0.4 \%$ or $0.6 \%$ Bio Rhizotonic $(10 \mathrm{~mL})$ after planting and 10 days later; RH $0.4 \% \times 3$, RH $0.6 \% \times 3$-watering with $0.6 \%$ Bio Rhizotonic $(10 \mathrm{~mL})$ after planting, 10 and 20 days later; RJ $0.1 \%$, RJ $0.2 \%$, RJ $0.4 \%$-watering with $0.1 \%, 0.2 \%$, or $0.4 \%$ Root Juice ${ }^{\mathrm{TM}}(10 \mathrm{~mL})$ after planting; BR $0.012 \%$, BR $0.02 \%$-watering with $0.012 \%$ or $0.02 \%$ Bio Roots $(10 \mathrm{~mL})$ after planting. Different small letters indicate significant interactions between phenological stage and treatment (two-way ANOVA). Different capital letters indicate significant differences between phenological stages. The Duncan's test $(\alpha=0.05)$ was used. 


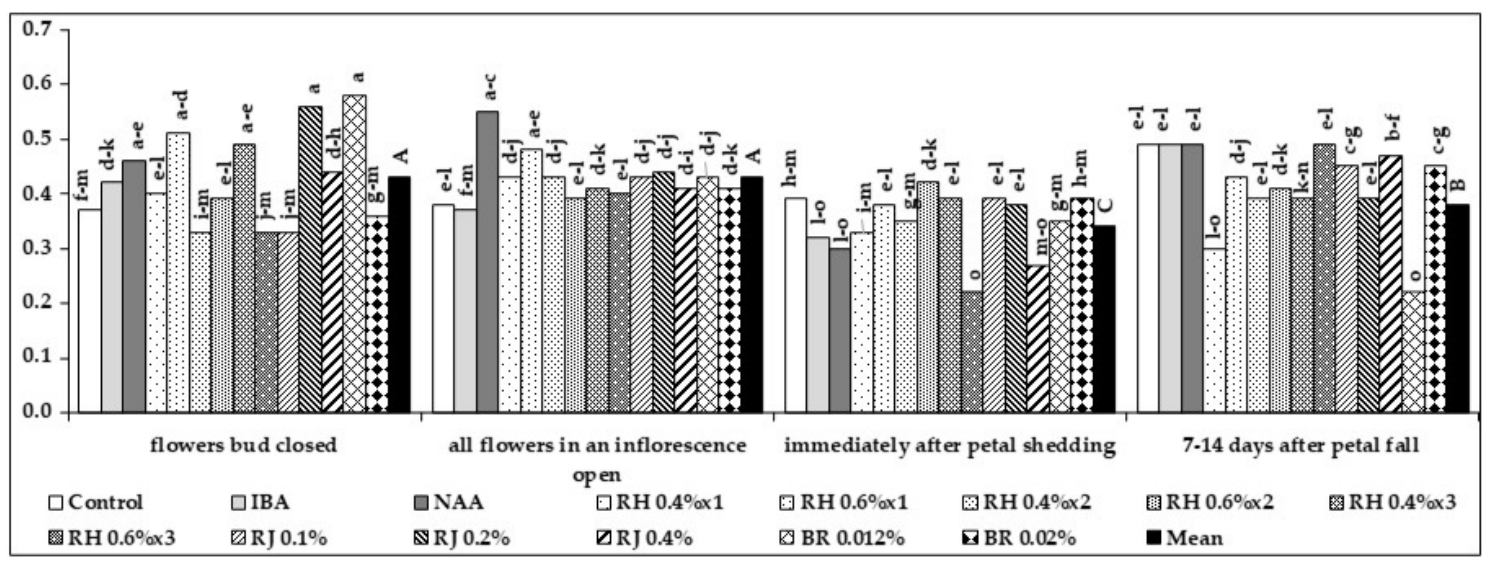

Figure 10. The influence of rooting enhancers on carotenoids content ( $\left.\mathrm{mg} \mathrm{g}^{-1} \mathrm{FW}\right)$ in leaves of Rosa 'Maiden's Blush' cuttings harvested from shoots in four phenological stages of shoots. Control—the control cuttings; IBA $0.4 \%$-Ukorzeniacz $\mathrm{A}_{\text {aqua }}\left(0.4 \%\right.$ IBA); NAA $0.2 \%$-Ukorzeniacz $\mathrm{B}_{\text {aqua }}(0.2 \%$ NAA); RH $0.4 \% \times 1$, RH $0.6 \% \times 1$-watering with $0.4 \%$ or $0.6 \%$ Bio Rhizotonic $(10 \mathrm{~mL})$ after planting; $\mathrm{RH} 0.4 \% \times 2$, RH $0.6 \% \times 2$-watering with $0.4 \%$ or $0.6 \%$ Bio Rhizotonic $(10 \mathrm{~mL})$ after planting and 10 days later; RH $0.4 \% \times 3$, RH $0.6 \% \times 3$-watering with $0.6 \%$ Bio Rhizotonic $(10 \mathrm{~mL})$ after planting, 10 and 20 days later; RJ $0.1 \%$, RJ $0.2 \%$, RJ $0.4 \%$-watering with $0.1 \%, 0.2 \%$, or $0.4 \%$ Root Juice ${ }^{\mathrm{TM}}(10 \mathrm{~mL})$ after planting; BR $0.012 \%$, BR $0.02 \%$-watering with $0.012 \%$ or $0.02 \%$ Bio Roots $(10 \mathrm{~mL})$ after planting. Different small letters indicate significant interactions between phenological stage and treatment (two-way ANOVA). Different capital letters indicate significant differences between phenological stages. The Duncan's test $(\alpha=0.05)$ was used.

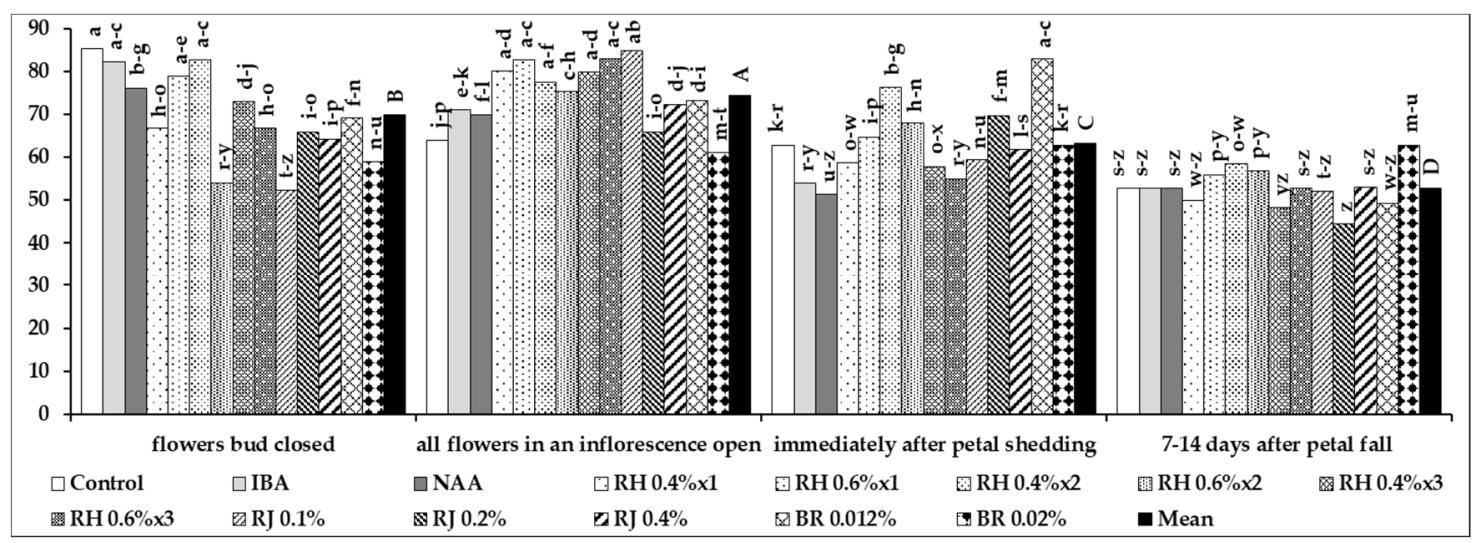

Figure 11. The influence of rooting enhancers on soluble proteins content $\left(\mu \mathrm{g} \mathrm{mg}^{-1} \mathrm{FW}\right)$ in leaves of Rosa 'Maiden's Blush' cuttings harvested from shoots in four phenological stages of shoots. Control—the control cuttings; IBA $0.4 \%$-Ukorzeniacz $\mathrm{A}_{\text {aqua }}\left(0.4 \%\right.$ IBA); NAA $0.2 \%$-Ukorzeniacz $\mathrm{B}_{\text {aqua }}(0.2 \%$ NAA); RH $0.4 \% \times 1$, RH $0.6 \% \times 1$-watering with $0.4 \%$ or $0.6 \%$ Bio Rhizotonic $(10 \mathrm{~mL})$ after planting; $\mathrm{RH} 0.4 \% \times 2$, RH $0.6 \% \times 2$-watering with $0.4 \%$ or $0.6 \%$ Bio Rhizotonic $(10 \mathrm{~mL})$ after planting and 10 days later; RH $0.4 \% \times 3$, RH $0.6 \% \times 3$-watering with $0.6 \%$ Bio Rhizotonic $(10 \mathrm{~mL})$ after planting, 10 and 20 days later; RJ $0.1 \%$, RJ $0.2 \%$, RJ $0.4 \%$-watering with $0.1 \%, 0.2 \%$, or $0.4 \%$ Root Juice ${ }^{\mathrm{TM}}(10 \mathrm{~mL})$ after planting; BR $0.012 \%$, BR $0.02 \%$-watering with $0.012 \%$ or $0.02 \%$ Bio Roots $(10 \mathrm{~mL})$ after planting. Different small letters indicate significant interactions between phenological stage and treatment (two-way ANOVA). Different capital letters indicate significant differences between phenological stages. The Duncan's test $(\alpha=0.05)$ was used.

\subsection{The Changes of Qualitative and Quantitative Parameters of Leaves Affect the Rooting Percentage}

The correlation analysis of the rooted single-node stem cuttings of 'Maiden's Blush' derived from of all phenological stages (M1-M4) showed a strict relationship between the increase of rooting percentage and higher percentage of rooted cuttings with retained stock plant leaf, total leaf area, 
length of young shoot, and the contents of chlorophyll a/b, carotenoids, and soluble proteins (Table 3). The increase of the cutting length of young shoots correlated positively with increasing total leaf area, contents of chlorophyll a/b, carotenoids, and soluble proteins in the leaves (Table 3). This phenomenon is related to the growth of young leaves. The cuttings with young shoots showed a tendency to drop off the stock plant leaf during the rhizogenesis process, and, consequently, there was a decrease in the total leaf area in cutting (Table 3). The increased percentage of rooted cuttings with young shoots correlated with the decrease of soluble protein content in leaves. The increase in the contents of soluble proteins, chlorophyll $\mathrm{a} / \mathrm{b}$, and carotenoids correlated with each other and were ambiguously related to the increase in the length of shoot and rooting percentage (Table 3).

Table 3. Correlations matrices between rooting percentage and growth parameters, pigments, and soluble proteins content for cuttings derived from all phenological stages of shoots together in Rosa 'Maiden's Blush'.

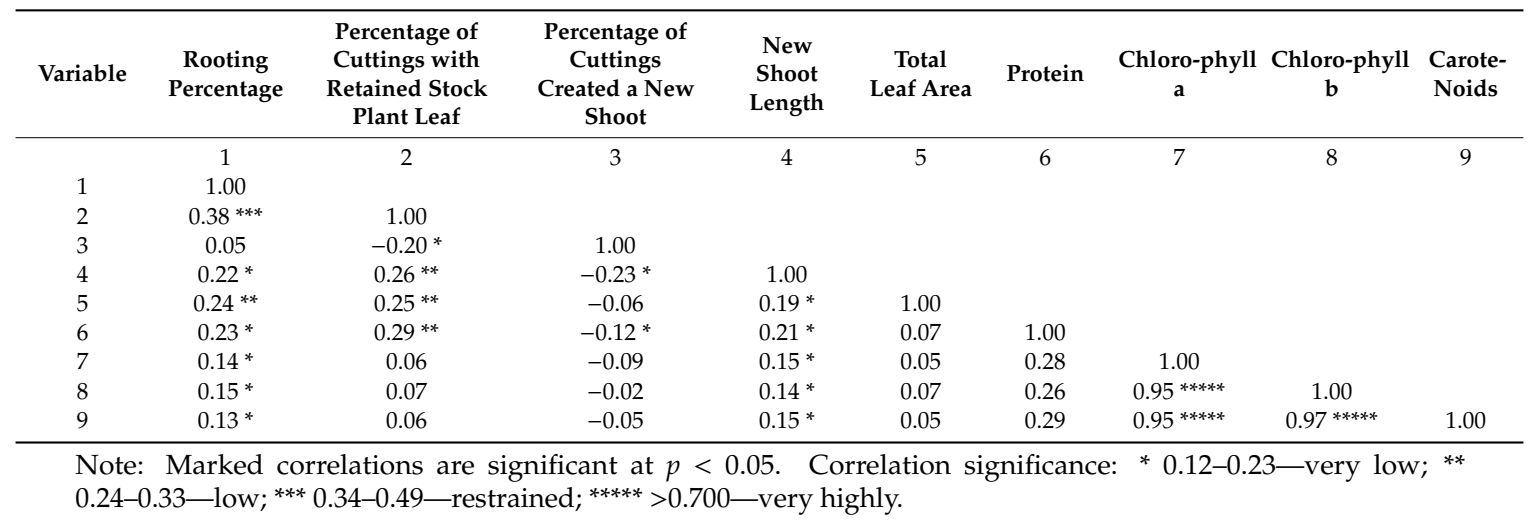

The decrease in the rooting percentage of 'Maiden's Blush' derived from shoots with all flower buds closed (M1) was correlated with the decrease of soluble protein content in leaves (Table 4).

Table 4. Correlations matrices between rooting percentage and growth parameters, pigments, and soluble proteins content for cutting derived from shoots with flower buds closed in Rosa 'Maiden's Blush'.

\begin{tabular}{|c|c|c|c|c|c|c|c|c|c|}
\hline Variable & $\begin{array}{c}\text { Rooting } \\
\text { Percen-Tage }\end{array}$ & $\begin{array}{c}\text { Percentage of } \\
\text { Cuttings with } \\
\text { Retained Stock } \\
\text { Plant Leaf }\end{array}$ & $\begin{array}{l}\text { Percentage of } \\
\text { Cuttings } \\
\text { Created a New } \\
\text { Shoot }\end{array}$ & $\begin{array}{c}\text { New } \\
\text { Shoot } \\
\text { Length }\end{array}$ & $\begin{array}{c}\text { Total } \\
\text { Leaf Area }\end{array}$ & Protein & $\begin{array}{l}\text { Chloro-phyll } \\
\text { a }\end{array}$ & $\begin{array}{l}\text { Chloro-phyll } \\
\text { b }\end{array}$ & $\begin{array}{l}\text { Carote- } \\
\text { Noids }\end{array}$ \\
\hline 1 & 1.00 & & & & & & & & \\
\hline 2 & 0.17 & 1.00 & & & & & & & \\
\hline 3 & 0.09 & 0.15 & 1.00 & & & & & & \\
\hline 6 & $-0.25^{* *}$ & 0.02 & -0.07 & -0.05 & -0.19 * & 1.00 & & & \\
\hline 7 & -0.09 & -0.10 & $-0.29 * *$ & 0.08 & -0.10 & 0.06 & 1.00 & & \\
\hline 8 & -0.07 & -0.08 & $-0.26 * *$ & 0.07 & -0.08 & 0.11 & $0.95^{* * * *}$ & 1.00 & \\
\hline 9 & -0.08 & -0.12 & $-0.28 * *$ & 0.09 & -0.09 & 0.14 & $0.96^{* * * *}$ & $0.97^{* * * *}$ & 1.00 \\
\hline
\end{tabular}

The decrease in the percentage of cuttings with young shoots correlated with the decrease in the length of shoots and ambiguously pigment content. The increased total leaf area correlated with the decrease of soluble protein content in leaves. The increases in the content of chlorophylls a and $b$ and carotenoids were interrelated (Table 4).

The increase in the rooting percentage of cuttings of 'Maiden's Blush' derived from shoots with flowers open (M2) was positively correlated with the increase in the percentage of rooted cuttings with retained stock plant leaf, total leaf area, and soluble protein content. The increase in the percentage of 
cuttings with young shoots of 'Maiden's Blush' was related to the increasing length of the shoots and total leaf area (Table 5).

Table 5. Correlations matrices between rooting percentage and growth parameters, pigments, and soluble proteins content for cutting derived from shoots with flowers opened in Rosa 'Maiden's Blush'.

\begin{tabular}{|c|c|c|c|c|c|c|c|c|c|}
\hline Variable & $\begin{array}{c}\text { Rooting } \\
\text { Percen-Tage }\end{array}$ & $\begin{array}{l}\text { Percentage of } \\
\text { Cuttings with } \\
\text { Retained Stock } \\
\text { Plant Leaf }\end{array}$ & $\begin{array}{l}\text { Percentage of } \\
\text { Cuttings } \\
\text { Created a New } \\
\text { Shoot }\end{array}$ & $\begin{array}{c}\text { New } \\
\text { Shoot } \\
\text { Length }\end{array}$ & $\begin{array}{c}\text { Total } \\
\text { Leaf Area }\end{array}$ & Protein & $\begin{array}{l}\text { Chloro-phyll } \\
\text { a }\end{array}$ & $\begin{array}{c}\text { Chloro-phyll } \\
\text { b }\end{array}$ & $\begin{array}{l}\text { Carote- } \\
\text { Noids }\end{array}$ \\
\hline 1 & 1.00 & & & & & & & & \\
\hline 2 & $0.23 *$ & 1.00 & & & & & & & \\
\hline 3 & 0.14 & 0.07 & 1.00 & & & & & & \\
\hline 6 & -0.02 & 0.12 & 0.08 & -0.01 & -0.20 & 1.00 & & & \\
\hline 7 & 0.00 & 0.09 & 0.02 & -0.04 & 0.07 & 0.13 & 1.00 & & \\
\hline 8 & 0.00 & 0.15 & 0.05 & -0.02 & 0.09 & 0.10 & $0.96^{* * * * *}$ & 1.00 & \\
\hline 9 & -0.01 & 0.16 & 0.05 & -0.01 & 0.06 & 0.14 & $0.94^{* * * * *}$ & $0.98^{* * * * *}$ & 1.00 \\
\hline
\end{tabular}

Rooting percentage of 'Maiden's Blush' cuttings derived from shoots immediately after petal shedding (M3) was positively correlated with the increase in the percentage of retained stock plant leaf in rooted cuttings. The percentage of rooted cuttings with retained stock plant leaf was significantly higher with increasing length of the shoots, but there was a decrease in the percentage of rooted cuttings with the young shoots. The increase of percentage rooted cuttings with young shoots was correlated with the increase in pigments and soluble protein content in leaves. The longer shoots resulted in increased total leaf area of rooted cuttings (Table 6).

Correlation analyses of the rooted cuttings of 'Maiden's Blush' derived from the shoots 7-14 days after petal shedding (M4) showed that there was no relationship between the increase or decrease in the values of related parameters of the aboveground part of cuttings and concentrations of pigments (Table 7). The decrease of soluble proteins in leaves correlated with higher rooting percentage and percentage of cuttings with young shoot. Moreover, the higher percentage of rooted cuttings with retained stock plant leaf correlated with increased shoot length (Table 7).

The increase in the content of chlorophylls $\mathrm{a}$ and $\mathrm{b}$ and carotenoids in leaves was interrelated in M1 and M2 ( Tables 4 and 5), while, in phenological stages M3 and M4, it was additionally interrelated with increasing soluble protein content ( Tables 6 and 7).

Table 6. Correlations matrices between rooting percentage and growth parameters, pigments, and soluble proteins content for cutting derived from shoots immediately after petal shedding in Rosa 'Maiden's Blush'.

\begin{tabular}{|c|c|c|c|c|c|c|c|c|c|}
\hline Variable & $\begin{array}{l}\text { Rooting } \\
\text { Percen-Tage }\end{array}$ & $\begin{array}{l}\text { Percentage of } \\
\text { Cuttings with } \\
\text { Retained Stock } \\
\text { Plant Leaf }\end{array}$ & $\begin{array}{l}\text { Percentage of } \\
\text { Cuttings } \\
\text { Created a New } \\
\text { Shoot }\end{array}$ & $\begin{array}{c}\text { New } \\
\text { Shoot } \\
\text { Length }\end{array}$ & $\begin{array}{c}\text { TOTAL } \\
\text { leaf Area }\end{array}$ & Protein & $\begin{array}{l}\text { CHLORO- } \\
\text { phyll a }\end{array}$ & $\begin{array}{l}\text { chloro- } \\
\text { phyll b }\end{array}$ & $\begin{array}{l}\text { Carote- } \\
\text { Noids }\end{array}$ \\
\hline 1 & 1.00 & & & & & & & & \\
\hline 2 & $0.32 * *$ & 1.00 & & & & & & & \\
\hline 3 & 0.14 & -0.21 * & 1.00 & & & & & & \\
\hline 6 & 0.00 & -0.19 * & $0.40^{* * *}$ & $-0.33 * *$ & -0.16 & 1.00 & & & \\
\hline 7 & 0.13 & -0.09 & 0.19 * & 0.06 & -0.08 & $0.35^{* * *}$ & 1.00 & & \\
\hline 8 & 0.10 & -0.06 & 0.22 * & 0.04 & 0.00 & $0.30^{* *}$ & $0.93^{* * * * *}$ & 1.00 & \\
\hline 9 & 0.12 & -0.08 & 0.23 * & 0.00 & 0.00 & $0.34^{* * *}$ & $0.93^{* * * * *}$ & $0.96^{* * * * *}$ & 1.00 \\
\hline
\end{tabular}


Table 7. Correlations matrices between rooting percentage and growth parameters, pigments, and soluble proteins content for cutting harvesting from shoots 7-14 days after petal shedding in Rosa 'Maiden's Blush'.

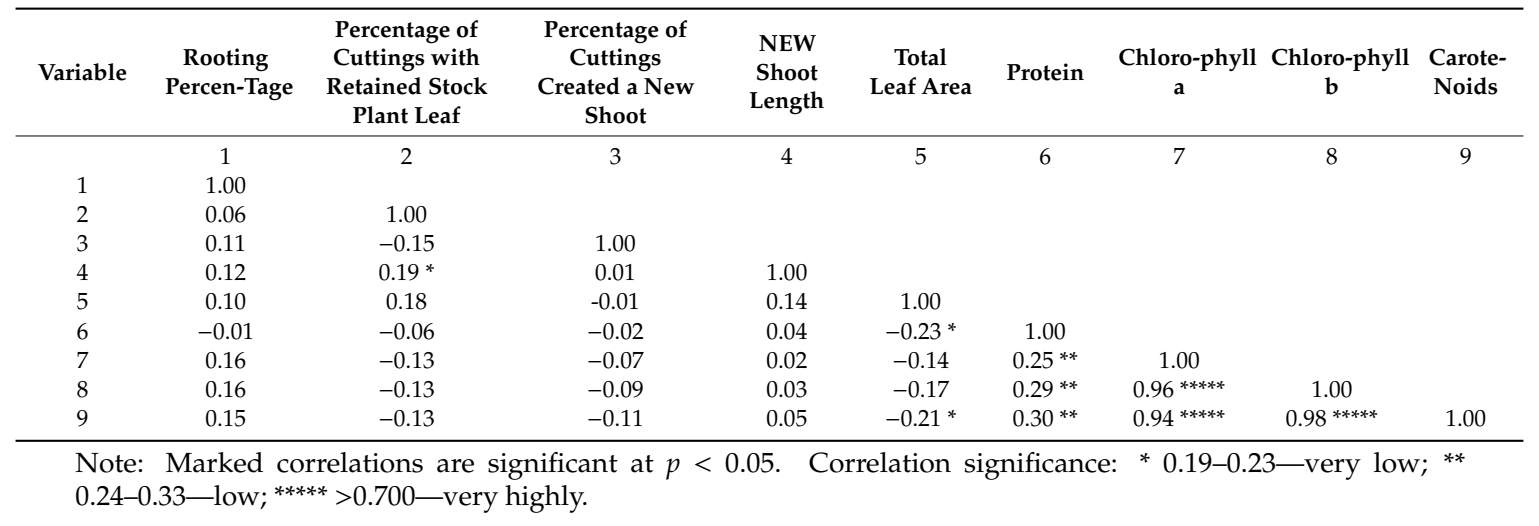

\section{Discussion}

The significance of phenological stage of shoot on rhizogenesis Rosa $\times a l b a$ 'Maiden's Blush' was proved in this work (Figures 3-11). The results of this study confirmed that the phenological stage of shoots harvested from stock plants for cuttings was decisive for the successful propagation of the once-blooming roses $[1,4,5,7,8,28]$. The plant preparations, Bio Rhizotonic, Root Juice ${ }^{\mathrm{TM}}$, and Bio Roots, did not show unequivocal impact on the rooting percentage of 'Maiden's Blush' (Figure 3). The tested rooting enhancers are related to the phenological stage of shoot and plant origin preparations in suitable concentration and have a favorable effect on the cuttings' quality and quantity (Figures 3-11). Previous works on rose rhizogenesis on once-blooming roses also showed that the phenological stage of stock plants affects the action of preparations used for the stimulation of rhizogenesis and subsequent rooting efficacy $[5,7,28]$. The other study on four cultivars of roses showed that the single-node leaf stem cuttings rooted without using the rooting stimulators exhibited various rooting percentages and a natural ability to rooting [8]. The response of rooting enhancers in roses was different in rooting percentage for the following phenological stages of shoots designated for cuttings [5,7,28], but in the case of low natural rooting ability in 'Hurdals' derived from shoots 7-14 days after petal fall, none of the rooting preparations affected improvement rooting percentage [5]. In this research, in the case of 'Maiden's Blush', especially for cuttings in M1-M3, the use of plant preparations seemed to increase the rooting percentage in contrast to decrease using $0.4 \%$ IBA and $0.2 \% \mathrm{NAA}$; however, the results were not statistically significant comparing to the control in the same phenological stage (Table 4).

The seasonal changes in plant tissues are natural processes $[8,12,13]$ occurring in stock plant of roses and in difficult-to-root cuttings during the prolonged rhizogenesis $[7,8]$. The cuttings are exposed to similar stresses as cut flowers $[19,20]$. Previous research showed that the seasonal changes in chlorophyll $\mathrm{a} / \mathrm{b}$ and carotenoids in leaves if shoots of four phenological stages (flower buds closed, all flowers in an inflorescence open, immediately after petal shedding, and 7-14 days after petal fall) of stock plant harvested for cuttings had an effect on the rooting percentage of rose 'Maiden's Blush' and 'Semiplena', while the content of proteins did not affect this parameter [8]. In this research, the correlation analysis showed the relationship between the rooting percentage and the level of chlorophyll $\mathrm{a} / \mathrm{b}$ and carotenoids in rooted cuttings for the means for all phenological stages and the content of soluble proteins both in correlation with all results and in M1 phase separately. In the research conducted on different cultivars of Juniperus treated with IBA and NAA, no relation was found between the content of proteins and the rhizogenesis ability [45]. However, the experiment on Rosa gallica 'Duchesse d'Angoulême' indicated that the use of tested biostimulants in suitable concentration influenced the ability of rooting to increase the content of chlorophyll and protein. The changes in the content of chlorophyll did not affect the obtained rooting percentage of this rose. Moreover, it was suggested that biostimulants do not affect the rooting capacity with increase in protein content [7]. 
In this study on 'Maiden's Blush', a dominant significant correlation was observed between the increase of soluble protein content and increase of rooting percentage in the results for all phases (Table 3). Simultaneously, the increase of soluble proteins correlated with the increase in the percentage of cuttings with retained stock plant leaf and young shoot and length of young shoot and increase in the content of chlorophyll a and b and carotenoids. The previous research confirmed that 'Maiden's Blush' is susceptible for natural ageing processes [8].

One of the favorable responses of plant biostimulants (LDPH-Legume-derived protein hydrolysate and TPE-Tropical plant extract) application is an increase in chlorophyll $\mathrm{a}, \mathrm{b}$ and total, as well as carotenoids, compared to extract seaweed Ecklonia maxima in cultivation of baby lettuce plants [46]. However, the use of seaweeds and seaweed products for cultivated plants also increased the chlorophyll content in leaves [32,36]. Use of a low concentration of Ascophyllum nodosum extract on soil or on foliage of tomatoes resulted in increasing chlorophyll content in leaves [38] and in rooted ninebark stem cuttings after the use Goteo (Ascophyllum nodosum extract) [47]. However, in the research on Brassica napus, the chlorophyll content and net photosynthetic rate showed contradictory results after the application of Ascophyllum nodosum L. extract [14].

The leaf blade turned yellow with visible coloration after changes in the chlorophyll content in leaves [17]. The key to the increase in rooting percentage of rose 'Maiden's Blush' is the leaf. The higher percentage of retained stock plant leaf in M2 correlated with the rooting percentage; however, the relation with good condition of cuttings may increase the percentage of cuttings with young shoot and consequently increase the total leaf area (Table 5). The increase of percentage cuttings with retained stock plant leaf in M2 and M3 affects the young shoots percentage and increases the pigments and proteins, suggesting indirectly the effect on rooting percentage (Tables 4 and 5). The progressive aging processes suggested decrease in chlorophyll $\mathrm{a} / \mathrm{b}$ content and were related to seasonal changes of stock plant [8], thereby increasing the percentage of retained stock plant leaf in M3, but decreasing the percentage of cuttings with young shoot (Table 5). Cuttings derived from M4 shoots using biostimulants in proper concentration increased the percentage of cuttings with young shoot, total leaf area, and content of soluble proteins in leaves (Table 6). However, the aging processes are probably inhibited during rhizogenesis by biostimulants [7]. It is proven that the use of commercial biostimulants increased the level of chlorophyll a/b in leaves, e.g., Crop $+{ }^{\circledR}$ and Seed $+{ }^{\circledR}[36]$, Retrosal ${ }^{\circledR}$ [37], and algal extracts [38].

Metabolic changes during leaf senescence leading to death of plant [48] include the hydrolysis of proteins, lipids, nucleic acids, and pigments that were accumulated during the growth phase [49]. The total content of soluble proteins in each shoot phenological stage in the stock plant varied depending on the cultivar of roses, and after rooting without rooting enhancers, it decreased in 'Maiden's Blush' [8]. The aforementioned results of the experiment conducted on 'Maiden's Blush' cuttings suggested that the plant preparations may increase the content of soluble proteins, percentage of cuttings with young shoot, and length of young shoot and positively affect the conditions of cuttings, while indirectly affecting the rooting percentage.

\section{Conclusions}

The previous research on roses by stem cuttings showed that the effectiveness of this method of propagation was oft fallible and should be verified for individual cultivar before applying $[1,2,8,35]$. This research indicated the key role of phenological stage of shoots used for the cuttings of Rosa 'Maiden's Blush'. The second key in propagation success is a leaf. Although the plant preparations Bio Rhizotonic, Root Juice ${ }^{\mathrm{TM}}$, and Bio Roots did not show unequivocal impact on the rooting percentage of 'Maiden's Blush', they may successfully replace the traditional rooting powders containing IBA or NAA in difficult-to-root roses during rhizogenesis. However, the cost of using the plant-origin preparations is higher. On the platform "ebay" the price of $5 \mathrm{~L}$ Bio Rhizotonic is ca. \$280, Root Juice ${ }^{\mathrm{TM}}$ : ca. $\$ 220$, and $250 \mathrm{~mL}$ of Bio Roots-ca. $\$ 80$. The prices of $100 \mathrm{~g}$ powder rooting enhancers (NAA, IBA) are ca. $\$ 10$. The action of plant origin preparations is related to the phenological stage of shoot, but it 
has a favorable effect on the cuttings' quality and quantity. Their action also affected positively higher soluble proteins and also chlorophyll content suppressing the aging effect in stress conditions of rooting. This result confirms the positive action that can enhance the assumptions of the directive 91/414/EEC, 2009/128/WE (OJEU) in relation to the use of alternatives to chemicals in plant nursery production.

Author Contributions: Conceptualization, M.J.M.; methodology, M.J.M., M.N., and K.W.; software, M.J.M.; validation, M.J.M.; formal analysis, M.J.M., M.N., and K.W.; investigation, M.J.M., K.W., and M.N.; resources, M.J.M.; data curation, M.J.M, K.W., and M.N.; writing—original draft preparation, M.J.M.; writing-review and editing, M.J.M.; visualization, M.J.M.; supervision, M.J.M.; project administration, M.J.M.; funding acquisition, M.J.M. All authors have read and agreed to the published version of the manuscript.

Funding: This work was supported by National Science Centre 2011-2014 (research project no. NN 310008240).

Acknowledgments: Many thanks to commercial nursery M. M. Kryt in Wola Prażmowska for professional staff assistance and place for the experiment.

Conflicts of Interest: The authors declare no conflict of interest. The authors also confirm that funders had no role in the design of the study; in the collection, analyses, or interpretation of data; in the writing of the manuscript; or in the decision to publish the results.

\section{References}

1. Moroz, E.K. Korniesoobstwiennyje rozy w Nacionalnom Parkie 'Sofiewka'; Nacionalna Akademia Nauk Ukrainy; Centralny Botanicznyj Sad: Umań, Ukraine, 2006.

2. Gustavsson, L.-Å. Rosen Leksikon; Rosinante: Copenhagen, Denmark, 1999; p. 138.

3. Hartmann, H.T.; Kester, D.E.; Davies, F.T.; Geneve, R.L. Plant Propagation, Principles and Practices, 7th ed.; Prentice-Hall: Englewood Cliffs, NJ, USA, 2011.

4. Pihlajaniemi, H.; Siurainen, M.; Rautio, P.; Laine, K.; Peteri, S.L.; Huttunen, S. Field evaluation of phenology and success of hardy, micropropagated old shrub roses in northern Finland. Acta Agric. Scand. Sect. B-Soil Plant Sci. 2005, 55, 275-286.

5. Monder, M.J.; Pacholczak, A. Rhizogenesis and concentration of carbohydrates in cuttings harvested at different phenological stages of once-blooming rose shrubs and treated with rooting stimulants. Biol. Agric. Hortic. 2020, 36, 53-70. [CrossRef]

6. Hoşafçi, H.; Arslan, N.; Sarihan, E.O. Propagation of dog rose (Rosa canina L.) plants by softwood cuttings. Acta Hortic. 2005, 690, 139-142. [CrossRef]

7. Monder, M.J.; Niedzielski, M.; Woliński, K. Effect of rooting preparations on protein, chlorophyll and carotenoid content in leaves of Rosa gallica 'Duchesse d'Angoulême' cuttings. Dendrobiology 2014, 72, $29-40$. [CrossRef]

8. Monder, M.J.; Niedzielski, M.; Woliński, K.; Pacholczak, A. The impact of seasonal changes in plant tissue on rhizogenesis of stem cuttings of the once flowering roses. Not. Bot. Horti. Agrobo. 2016, 4, 92-99. [CrossRef]

9. Costa, J.M. The Role of the Leaf in Growth Dynamics and Rooting of Leafy Stem Cuttings of Rose. Ph.D. Thesis, Wageningen University, Wageningen, The Netherlands, 2002.

10. Costa, J.M.; Challa, H. The effect of the original leaf area on growth of softwood cuttings and planting material of rose. Sci. Hortic. 2002, 95, 111-121. [CrossRef]

11. Okoro, O.O.; Grace, J. The physiology of rooting Populus cuttings. I. Carbohydrates and photosynthesis. Physiol. Plant. 1976, 36, 133-138. [CrossRef]

12. Afitlhile, M.M. Constituent Processes of Leaf Senescence in Hordeum vulgare cv. Dyan. Master's Thesis, Rhodes University, Grahamstown, South Africa, 1993.

13. Gitelson, A.; Merzlyak, M.N. Spectral reflectance changes associated with autumn senescence of Aesculus hippocastanum L. and Acer platanoides L. leaves. Spectral features and relation to chlorophyll estimation. J. Plant Physiol. 1994, 143, 286-292. [CrossRef]

14. Jannin, L.; Arkoun, M.; Etienne, P.; Laïné, P.; Goux, D.; Garnica, M.; Fuentes, M.; Francisco, S.S.; Baigorri, R.; Cruz, F.; et al. Brassica napus growth is promoted by Ascophyllum nodosum L. Le. Jol. Seaweed extract, microarray analysis and physiological characterization of N, C, and S metabolism. J. Plant Growth Regul. 2013, 31, 32-52. [CrossRef]

15. Wojdyła, A. Effectiveness of Atonik SL in the control of powdery mildew, black spot and rust. Folia Hortic. 2004, 16, 175-181. 
16. Whapham, C.A.; Blunden, G.; Jenkins, T.; Hankins, S.D. Significance of betaines in the increased chlorophyll content of plants treated with seaweed extract. J. Appl. Phycol. 1993, 5, 231-234. [CrossRef]

17. Volfová, A.; Chvojka, L.; Friedrich, A. The effect of kinetin and auxin on the chloroplast structure and chlorophyll content in wheat coleoptiles. Biol. Plantarum. 1978, 20, 440-445. [CrossRef]

18. Czerpak, R.; Dobrzyń, P.; Krotke, A.; Kicińska, E. The effect of auxins and salicylic acid on chlorophyll and carotenoid contents in Wolffia Arrhiza (L.) Wimm. (Lemnaceae) growing on media of various trophicities. Pol. J. Environ. Stud. 2002, 11, 231-235.

19. Ranwala, A.; Miller, W.B. Effects of gibberellin treatments on flower and leaf quality of cut hybrid lilies. Acta Hortic. 2002, 570, 205-210. [CrossRef]

20. Skutnik, E.; Rabiza-Świder, J. Longevity of cut shoots of Molucella laevis L. as affected by flower preservatives and growth regulators. Folia Hortic. 2004, 16, 167-173.

21. Official Journal of the European Union. Directive 2009/128/EC of the European Parliament and of the Council of 21 October 2009 establishing a framework for Community action to achieve the sustainable use of pesticides. Off. J. Eur. Union 2009, 309, 71-86.

22. Vasconcelos, A.C.F.; Chaves, L.H.G. Biostimulants and their role in improving plant growth under abiotic stresses. In Biostimulants in Plant Science; IntechOpen: London, UK, 2019. [CrossRef]

23. Khan, W.; Rayrath, U.P.; Subramanian, S.; Jithesh, M.N.; Rayorath, P.; Hodges, D.M.; Critchley, A.T.; Craigie, J.S.; Norrie, J.; Prithiviraj, B. Seaweed extracts as biostimulants of plant growth and development. J. Plant Growth Regul. 2009, 28, 386-399. [CrossRef]

24. Thorsen, M.K.; Woodward, M.; McKenzie, B.M. Kelp (Laminaria digitata) increases germination and affects rooting and plant vigour in crops and native plants from an arable grassland in the Outer Hebrides, Scotland. J. Coast. Conserv. 2010, 14, 239-247. [CrossRef]

25. Couée, I.; Hummel, I.; Sulfon, C.; Gouesbet, G.; Amrani, A. Involvement of polyamines in root development. Plant Cell Tiss Org. 2004, 76,1-10. [CrossRef]

26. Pacholczak, A.; Szydło, W.; Jacygrad, E.; Federowicz, M. Effect of auxins and the biostimulator Algaminoplant on rhizogenesis in stem cuttings of two dogwood cultivars (Cornus alba 'Aurea' and 'Elegantissima'). Acta Sci. Pol. Hortorum Cultus 2012, 11, 93-103.

27. Pacholczak, A.; Szydło, W.; Petelewicz, P.; Szulczyk, K. The effect if Algaminoplant on rhizogenesis in stem cuttings of Physocarpus opulifolius 'Dart's Gold' and 'Red Baron'. Acta Sci. Pol. Hortorum Cultus 2013, 12, 105-116.

28. Monder, M.J.; Kozakiewicz, P.; Jankowska, A. Anatomical structure changes in stem cuttings of rambler roses induced with plant origin preparations. Sci. Hortic. 2019, 255, 242-254. [CrossRef]

29. Official Journal of the European Union. Regulation (EC) No 1107/2009 of the European Parliament and of the Council of 21 October 2009 concerning the placing of plant protection products on the market and repealing Council Directives 79/117/EEC and 91/414/EEC. Off. J. Eur. Union 2009, 309, 1-50.

30. United States Department of Agriculture. National Organic Program. 2017. Available online: http: //www.ams.usda.gov/AMSv1.0/NOP2014 (accessed on 21 January 2017).

31. Organic Materials Review Institute. OMRI Products List, Web Edition. Available online: http://www.omri. org/sites/default/files/opl_pdf/complete_company.pdf (accessed on 17 January 2017).

32. Council Directive no. 91/414/EEC of concerning the placing of plant protection products on the market. Off. J. Eur. Union 1991, 230, 1-32.

33. Canna Continental. Bio Rhizotonic. Available online: http://www.biocanna-organics.ca/BioRhizotonic/ (accessed on 19 January 2017).

34. BioBizz Worldwide, B.V. Root Juice ${ }^{\mathrm{TM}}$. Available online: http://www.biobizz.com/products/\#root $\%$ c2\%b7juice (accessed on 19 January 2017).

35. General Hydroponics Europe. Bio Roots. Homepage. Available online: http://gb.eurohydro.com/bio_roots. html/ (accessed on 19 January 2017).

36. Morais, T.B.; Swarowsky, A.; Rodrigues, S.N.; Quadros, D.; Christofari, L.Z.; Posser, T.; Pivetta, M. Efeito dos bioestimulantes seed+ße crop+®no índice de clorofila total da soja sob estresse hídrico. Agric. Foco. 2018, 1, 166-171. [CrossRef]

37. Bulgari, R.; Trivellini, A.; Ferrante, A. Effects of two doses of organic extract based biostimulant on greenhouse lettuce grown under increasing $\mathrm{NaCl}$ concentrations. Front. Plant Sci. 2019, 9, 1870. [CrossRef] [PubMed] 
38. El-Baky, H.H.A.; Hussein, M.M.; El-Baroty, G.S. Algal extracts improve antioxidant defense abilities and salt tolerance of wheat plant irrigated with sea water. Afr. J. Biochem. Res. 2008, 2, 151-164.

39. Blunden, G.; Jenkins, T.; Liu, Y. Enhanced leaf chlorophyll levels in plants treated with seaweed extract. J. App. Phycol. 1997, 8, 535-543. [CrossRef]

40. Meier, U.; Bleiholder, H.; Brumme, H.; Bruns, E.; Mehring, B.; Proll, T.; Wiegand, J. Phenological growth stages of roses (Rosa sp.): Codification and description according to the BBCH scale. Ann. Appl. Biol. 2008, 154, 231-238. [CrossRef]

41. Moberg, U.; Winter, A.; Hyden, N.; Ek, K. Analysis of Monoclonal Antibodies during Production and Purification. A Review of Electrophoretic Methods. LKB INSTRUMENTS. Available online: https: //www.lkb.com.au/ (accessed on 28 October 2020).

42. Ghosh, S.; Gepstein, S.; Heikkila, J.J.; Dumbroff, E.B. Use of scaning densitometer or an ELISA Plate Reader for measurement of nanogram amounts of protein in crude extracts from biological tissues. Anal. Biochem. 1988, 169, 227-233. [CrossRef]

43. Arnon, D.I. Copper enzyme in isolated chloroplasts. Polyphenoloxidase in Beta vulgaris. Plant Physiol. 1949, 24, 1-15. [CrossRef]

44. Wójcik, A.R.; Laudański, Z. Planowanie i Wnioskowanie Statystyczne w Doświadczalnictwie; Wydawnictwo Naukowe PWN: Warsaw, Poland, 1989.

45. Szydło, W. Intensyfikacja Procesu Rozmnażania Krzewów Ozdobnych Przez Sadzonki Pędowe. Ph.D. Thesis, University of Life Science, Warsaw, Poland, 1999.

46. Mola, I.; Cozzolini, E.; Ottaiano, L.; Giordano, M.; Rouphael, G.; Mori, M. Effect of vegetal- and seaweed extract-based biostimulants on agronomical and leaf quality traits of plastic tunnel-grown baby lettuce under four regimes of nitrogen fertilization. Agronomy 2019, 9, 571. [CrossRef]

47. Pacholczak, A.; Nowakowska, K.; Mika, N.; Borkowska, M. The effect of the biostimulator Goteo on the rooting of ninebark stem cuttings. Folia Hortic. 2016, 28, 109-116. [CrossRef]

48. Smart, C.M. Gene expression during leaf senescence. New Phytol. 1994, 126, 419-448. [CrossRef]

49. Watanabe, M.; Balazadeh, S.; Tohge, T.; Erban, A.; Giavalisco, P.; Kopka, J.; Mueller-Roeber, B.; Fernie, A.; Hoefgen, R. Comprehensive dissection of spatiotemporal metabolic shifts in primary, secondary, and lipid metabolism during developmental senescence in Arabidopsis. Plant Physiol. 2013, 162, 1290-1310. [CrossRef]

Publisher's Note: MDPI stays neutral with regard to jurisdictional claims in published maps and institutional affiliations.

(C) 2020 by the authors. Licensee MDPI, Basel, Switzerland. This article is an open access article distributed under the terms and conditions of the Creative Commons Attribution (CC BY) license (http://creativecommons.org/licenses/by/4.0/). 